Nota Técnica

\title{
INCIDÊNCIA E IDENTIFICAÇÃO DE BACTÉRIAS EM PONTOS DE EXPOSIÇÃO E VENDA DE HORTIFRUTÍCOLAS: UM ESTUDO DE CASO
}

\section{BIOENG}

\author{
M. Z. Fabiano ${ }^{1}$, L. A. Forato ${ }^{2}$, O. B. G. Assis ${ }^{2 *}$, R. Bernardes-Filho ${ }^{2}$
}

${ }^{1}$ UFSCar - Programa de Pós-graduação em Biotecnologia, Universidade Federal de São Carlos, São Carlos, SP, Brasil

${ }^{2}$ EMBRAPA Instrumentação, LNNA - Laboratório Nacional de Nanotecnologia para o Agronegócio, São Carlos, SP, Brasil

Article history: Received 03 May 2017; Received in revised form 22 May 2017; Accepted 29 May 2017; Available online 30 June 2017.

\section{RESUMO}

As contaminações em frutas e hortaliças resultantes da atividade de patógenos geram significativas perdas na fase pós-colheita e na etapa de comercialização. Não somente uma sanitização inadequada dos pontos de amostragem e venda, mas a falta de boas práticas e manuseio em toda a cadeia favorece a incidência de podridão de origem microbiana e da contaminação secundária no ambiente de armazenamento e comércio. Assim, o objetivo deste trabalho foi o de gerar informações para orientar uma melhor sanitização fazendo uso de agentes antimicrobianos que tenham uma atuação mais eficiente no controle dos microorganismos que predominam nestes pontos de venda. Através de um estudo de caso, foi realizado amostragem em uma importante central de recebimento e comercialização de frutas e hortaliças no atacado e varejo, localizada em São Carlos, SP, sendo identificados 46 tipos de bactérias em diversos pontos de acondicionamento e venda. As gôndolas de hortaliças e os pratos da balança foram os locais de maior incidência microbiana. A maioria dos microorganismos identificados é do tipo Gram-positivo, contudo das 16 bactérias reconhecidas como Gram-negativas, 13 destas apresentaram média ou alta motilidade, sendo considerados organismos de alto potencial patógeno. Por meio de análise de material genético replicado por técnica de PCR (polymerase chain reaction), identificaram-se dois grupos Gram-negativos dominantes: Escherichia e Enterobacter, em diferentes cepas.

Palavras-chave: contaminação bacteriana, hortifrutícolas, pós-colheita, sanitização

\section{INCIDENCE AND IDENTIFICATION OF BACTERIA IN SPOTS OF EXPOSITION AND COMMERCIALIZATION OF FRUITS AND VEGETABLES: A CASE STUDY}

\begin{abstract}
The contamination of fruits and vegetables, due to pathogen activity, causes significant losses during postharvest and commercialization stage. Not solely an inadequate sanitization carried out on exposition and sales points, but also the lack of good practices and handling along the chain, favors the development of rots from microbial origin and secondary contamination along storage and commercialization conditions. Thus, the main aim of this study was to
\end{abstract}

odilio.assis@embrapa.br 
generate basic information useful for a better sanitization by using antimicrobial agents with efficiency in controlling the predominant microorganisms as identified in such sales spots. A case study was conducted by analyzing samples collected in an important commercial wholesale and retail market, specialized in the commercialization of fruits and vegetables, located in São Carlos, SP (Brazil), in which 46 types of bacteria were possible to be isolated and growth after sampling in several spots of exposition and commercialization. The grocery shelves and the scales were the points of higher microbial incidence. Most of the microorganisms were classified as gram-positive, though from 16 species identified as Gramnegative, 13 of them presented medium to high motility, being considered as organisms of elevate photogene potential. By means of genetic materials replication technique PCR (polymerase chain reaction), two dominant Gram-negative genera were identified: the Escherichia sp and Enterobacter sp., in different strains.

Keywords: postharvest; horticultural; microbial contamination; sanitization

\section{INTRODUÇÃO}

A incidência de micro-organismos patógenos no setor de hortifrutícolas é um sério problema de saúde pública. O manejo inadequado, associado a condições precárias de sanitização, armazenamento e comercialização podem levar a contaminações generalizadas e de difícil controle que resultam em riscos à saúde humana e perdas de caráter econômico. Também não é raro o uso de procedimentos condenáveis como a irrigação de áreas de cultivo com água de rios poluídos ou por efluentes de esgotos, uma prática comum no Brasil e em outros países em desenvolvimento (HANJIRA et al. 2012). Ou seja, apesar da rápida expansão do setor hortifrutícola brasileiro, alguns segmentos da cadeia ainda continuam frágeis e pautados pelo uso de procedimentos não apropriados e/ou ausentes de boas práticas que possam preservar a qualidade dos produtos.

Em condições normais, a maioria da flora microbiota em frutas e hortaliças tem origem no campo (JAY, 2005), embora acondicionamentos inadequados tenham sido também responsáveis pela proliferação das contaminações que ocorrem na condição pós-colheita (SATTOLO et al. 2010; SARANRAJ et al. 2012). Assim, não somente as desordens fisiológicas, mas aquelas de ordem microbiológica igualmente contribuem para perdas significativas no setor atacadista e varejista. Segundo SOMMER (2002), os patógenos, principalmente os quiescentes, são os que geram as maiores perdas, além de serem os responsáveis por boa parte de infecções diagnosticadas em humanos.

As doenças de origem microbianas transmitidas por frutas e hortaliças podem ser classificadas em duas categorias: 'intoxicação alimentar' e 'infecção alimentar' (MINISTÉRIO DA SAÚDE, 2010). A intoxicação alimentar ocorre pela ingestão das toxinas pré-formadas por micro-organismos no alimento consumido enquanto que na infecção alimentar, o patógeno é que é ingerido e se multiplica, causando danos no trato intestinal e demais órgãos. Ambas enfermidades contudo, têm origem nos diversos gêneros e microorganismos presentes nos alimentos.

Assim, levando em consideração as condições usuais de estocagem e a manipulação, buscou-se nesse trabalho identificar as principais bactérias incidentes nos pontos usuais de condicionamento e comercialização de hortifrutícolas em um estabelecimento comercial. A identificação desses microorganismos é de utilidade para a tomada de decisões e aplicações de processos de sanitização mais específicos e, por conseguinte, mais eficientes na redução da disseminação bacteriana. 


\section{MATERIAL E MÉTODOS}

A coleta de material foi realizada em diferentes pontos de amostragem e venda de uma importante central de recebimento, distribuição e comercialização no atacado e varejo de hortifrutícolas localizado na cidade de São Carlos, SP. Este estabelecimento, de alta circulação de produtos, recebe tanto a produção local e regional, como produtos oriundos do CEASA-SP, capital. Para a venda no varejo a maioria dos produtos fica exposta em gôndolas convencionais ou acondicionados em caixas de madeiras ou plástico, sem qualquer tipo de isolamento ambiental ou controle de temperatura.

Os processos de higienização e disposição dos produtos observados no estabelecimento seguem os procedimentos comuns adotados na maioria de locais similares, ou seja, descarte dos resíduos não comercializados, lavagem com água corrente e detergente das bandejas e gôndolas e esporadicamente uma sanitização geral, que consiste em uma lavagem dos pontos de exposição, chão e balcões, fazendo uso de solução aquosa a base de produtos comerciais contendo cloro. Esta sanitização é normalmente realizada no inicio de cada semana ou ao substituir os produtos em exposição, embora não tenha uma frequência definida, segundo informações fornecidas pelos funcionários locais.

$\mathrm{Na}$ análise realizada neste trabalho, os contaminantes foram coletados no interior de geladeiras e freezers, sobre a superfície de pratos de balanças, gôndolas de hortaliças (alface, repolho e vargem) e diretamente da casca de frutos tomados aleatoriamente (maçãs, peras, goiabas e mamões).

As amostras microbianas foram coletadas com auxilio de "swabs" esterilizados, devidamente identificados, seguidos de inoculação e cultivo em meio Luria-Bertani (LB) líquido, na temperatura de $37{ }^{\circ} \mathrm{C}$ por $24 \mathrm{~h}$. As coletas foram realizadas em triplicata e em dias alternados (segunda, quarta e sexta-feira) e a inoculação se deu por esgotamento em placas de Petri (Agar) por mais $24 \mathrm{~h}$ também a $37{ }^{\circ} \mathrm{C}$. Assumiu-se assim que a primeira coleta foi realizada após o procedimento de higienização, conforme informado e adotado pelo estabelecimento

A primeira identificação dos organismos foi conduzida pelo teste de Coloração Diferencial de Gram, seguindo os procedimentos descritos por MORETTI (2008), em amostras preparadas sobre lâminas para microscopia. Empregaram-se corante cristal violeta (Vetec), corante mordente lugol (Synth) e corante fucsina (Hoechst). Após os procedimentos de fixação e secagem as lâminas foram observadas em microscópio ótico.

Para confirmação da técnica de coloração de Gram foi conduzido o teste de solubilidade em $\mathrm{KOH}$ ou método de Ryce. Este método consiste em transferir uma porção da colônia bacteriana para uma gota da solução de $\mathrm{KOH}$ (a $3 \%$ m/v) em lâmina limpa, flambada e esfriada ao ar. $\mathrm{Na}$ presença de bactérias Gram-positivas, as células se dispersam e não há aumento da viscosidade da suspensão. Já para as Gramnegativas, a suspensão se torna viscosa. $\mathrm{O}$ Método de Ryce é um procedimento alternativo e rápido para a detecção de bactérias Gram-negativas sem o uso de corante (HALBIAN et al. 1981).

Em frutos e hortaliças as bactérias do tipo Gram-negativas com "alta" ou "média motilidade" são consideradas mais patogênicas (POMMERVILLE, 2013). Verificou-se assim, esta característica nas culturas isoladas de micro-organismos gram-negativos por crescimento em meio semi-sólido LB e observação microscópica. Dois procedimentos foram adotados para a confirmação da motilidade: i) por espalhamento, na qual as bactérias são incubadas a $32{ }^{\circ} \mathrm{C}$ por 24 horas em orifício em meio de cultura LB em um tubo inclinado, observando a turbidez gerada no entorno e o crescimento das colônias além da semeadura, e ii) por análise microscópica realizada após a 
incubação, na qual a motilidade é registrada quando várias células individuais movem-se em várias direções (MARTINEZ et al. 2014). Para este último empregou-se microscópio ótico Olympus CX21 com lente de imersão em óleo.

A identificação do tipo de bactéria foi realizada em dez isolados por meio de amplificação de DNA total utilizando primers universais $16 \mathrm{~S}$ e posteriormente sequenciamento da região amplificada (DNA CONSULT, 2015). Para o sequenciamento o DNA foi isolado através de um termociclador e o material genético replicado por técnica de PCR (polymerase

\section{RESULTADOS E DISCUSSÃO}

\section{Identificação Microbiana}

A partir dos pontos de amostragem foi possível isolar um total de 46 colônias distintas, indicando que micro-organismos diversos populam simultaneamente os locais avaliados. Ao serem cultivados apresentam a formação de culturas mistas fazendo-se necessária a separação dos organismos. Inicialmente é possível a distinção dos organismos por seu aspecto visual (morfotipos) seguindo as características de pigmentação e superfície. A classificação morfológica teve por base as identificações presuntivas propostas por KIEL (2010), gerando a distribuição informativa apresentada na Figura 1. chain reaction). As reações foram realizadas utilizando o Kit DYEnamic ${ }^{\mathrm{TM}}$ GE (código US81090). Detalhes experimentais podem ser encontrados em Fabiano (2011). Nas análises das sequencias empregou-se o programa desenvolvido pela Embrapa Electropherogram quality analysis (EMBRAPA, 2015), que utiliza o índice Phred (ABURJAILE et al. 2015). A identificação final do micro-organismo teve por base o banco da National Center for Biotechnology Information (BLAST, 2015).

Com respeito ao local de coleta, as bancadas (gôndolas) nas quais ficaram dispostas os produtos para a compra foram os locais nos quais a presença de um maior número de bactérias distintas foram colhidas. Comparativamente, na bancada de repolhos foi identificado o maior número de contaminações (9 organismos distintos) e no interior da geladeira o menor número (1 micro-organismo). A distribuição da quantidade de colônias distintas em cada um dos pontos avaliados está disposta na Tabela 1 , o que permite a distinção quantitativa dos locais e ou produtos susceptíveis a maiores contaminações.

Tabela 1. Número de micro-organismos isolados nos pontos de venda e exposição

\begin{tabular}{lc}
\hline \multicolumn{1}{c}{$\begin{array}{c}\text { Ponto de } \\
\text { Isolamento }\end{array}$} & $\begin{array}{c}\text { Número de } \\
\text { bactérias distintas } \\
\text { identificadas }\end{array}$ \\
\hline Balança & 5 \\
Bancada alface & 7 \\
Bancada repolho & 9 \\
Bancada vargem & 7 \\
Geladeira & 1 \\
Freezer & 4 \\
\hline Superfície pera & 2 \\
Superfície goiaba & 4 \\
Superfície mamão & 4 \\
Superfície maçã & 3 \\
\hline
\end{tabular}




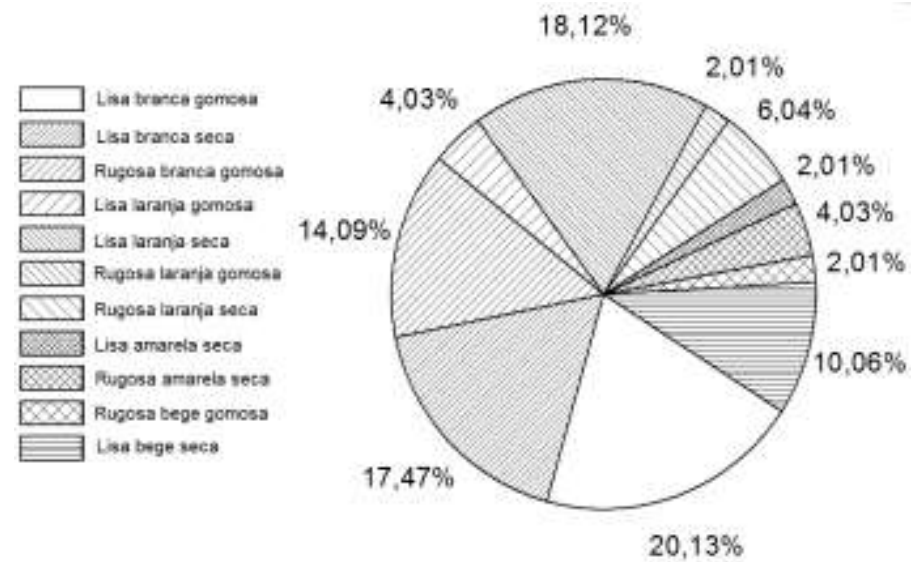

Figura 1. Distribuição porcentual das características dos micro-organismos isolados segundo identificação presuntiva (morfotipo) no meio de cultura.

Praticamente não foram observadas variações passíveis de serem tratadas estatisticamente entre as três amostras coletadas nos distintos dias de coleta. Ou seja, o número de bactérias crescidas a partir das amostragens realizadas nos pontos selecionados permaneceu constante independente do dia.

Pela análise de coloração de Gram identificou-se que destas, 24 bactérias eram Gram-positivas ( 15 cocos e 9 bacilos) e 16 Gram-negativas (bacilos), não sendo observado nenhum organismo no formato espiralado (espirilas). Durante a análise 6 amostras mostraram-se com contaminações múltiplas inviabilizando a diferenciação das estruturas de parede celular pelo método de coloração.

A caracterização da motilidade indicou que esta ocorre essencialmente nas espécies Gram-negativas, sendo das 16 espécies isoladas apenas 3 não acusaram motilidade. Todas as demais (13) apresentaram comportamento típico de média ou alta motilidade indicando bactérias de alto potencial patógeno.

A análise por ampliação de DNA (PCR) foi então conduzida nos isolados Gram-negativos possibilitando a identificação de dois gêneros dominantes, conforme dados dispostos na Tabela 2.

Tabela 2. Sequencia e identificação de espécies Gram-negativas com motilidade

\begin{tabular}{cccc}
\hline Acesso Gen Bank* & $\begin{array}{c}\text { Micro-organismo } \\
\text { Dominante }\end{array}$ & Similaridade & Alinhamento \\
\hline FJ422473.1 & Escherichia $s p$. & $96 \%$ & 551 \\
FJ422473.1 & Escherichia $s p$. & $95 \%$ & 573 \\
DQ013851.1 & Escherichia $s p$. & $97 \%$ & 843 \\
DQ013851.1 & Escherichia $s p$. & $97 \%$ & 856 \\
DQ013851.1 & Escherichia $s p$. & $88 \%$ & 645 \\
DQ013851.1 & Escherichia $s p$. & $89 \%$ & 647 \\
\hline HM461217.1 & Enterobacter $s p$. & $83 \%$ & 584 \\
HQ652601.1 & Enterobacter $s p$. & $82 \%$ & 558 \\
HQ143605.1 & Enterobacter $s p$. & $84 \%$ & 579 \\
HQ143605.1 & Enterobacter $s p$. & $84 \%$ & 579 \\
\hline
\end{tabular}

* http://www.ncbi.nlm.nih.gov/nuccorel

Por comparação das características moleculares depreende-se que os microorganismos com motilidade pertencem a cepas diferentes de um mesmo gênero, a saber Escherichia e Enterobacter. 
Considerações sobre procedimentos de sanitização

Os resultados obtidos a partir dessas amostragens indicam que os procedimentos usualmente adotados para a higienização são pouco eficientes na eliminação de bactérias e que a contaminação cruzada é favorecida nas condições usais de acondicionamento. De um modo geral a eliminação total de contaminantes biológicos em frutas $\mathrm{e}$ hortaliças é praticamente impossível considerando que os compostos desinfectantes têm um poder limitado de destruição. A etapa de maior incidência de contaminação é também de difícil identificação e pode ocorrer em diversos momentos da cadeia, seja na colheita, transporte, manuseio e comercialização. Contudo, na comercialização em particular, as contaminações podem ser minimizadas se identificados os principais patógenos de ocorrência local e se agentes sanitizantes apropriados forem empregados. Como as bactérias de caráter mais agressivo são as que apresentam maior motilidade, e aqui identificadas como as Gram-negativas, o uso de compostos apropriados (mas não exclusivos) ao combate dessas espécies podem elevar a eficiência da sanitização pela redução do número dos organismos dentro de níveis considerados seguros à saúde (ANDRADE, 2014).

As bactérias Gram-negativas são organismos anaeróbios ou anaeróbios facultativos podendo apresentar diferentes

\section{CONCLUSÕES}

De acordo com as análises, nos pontos de acondicionamento e vendas de frutas e hortaliças avaliados, mesmo quando submetidos a limpezas convencionais, apresentam a ocorrência de uma grande diversidade de bactérias favorecendo sua disseminação e contaminações secundárias.

Constatou-se que as gôndolas, assim como os pratos das balanças são os locais onde se prolifera o maior número de graus de tolerância ao oxigênio, o que torna esse grupo bastante heterogêneo. Normalmente a letalidade das Gramnegativas está relacionada à sua interação com o oxigênio produzindo as chamadas espécies reativas do oxigênio (EROs), em seu metabolismo (normalmente ânions superóxidos, peróxido de hidrogênio e radicais hidroxila em procariotos) que podem levar a desnaturação de membranas lipídicas, estruturas celulares e do DNA.

Neste caso, a desinfecção de equipamentos e instalações deve fazer uso de agentes reativos ricos em oxigênio em concentrações diversas (PINHEIRO et al. 2011; ANDRADE, 2014), sendo indicados os compostos quaternários de amônia, o ácido peracético, sais de sódio (carbonato, metassilicato e hidróxido) e o peróxido de hidrogênio, como agentes de elevada atividade antibacteriana frente cepas Gram-negativas. Para ação sobre grupos Gram-positivos esses agentes, e principalmente os compostos de amônia, devem ser associados ao hexaclorofeno e ao iodofor para uma melhor eficiência de sanitização.

Essas orientações são apenas indicativas, considerando que diversos fatores contribuem para a predominância de uma ou várias colônias ou de contaminações cruzadas por cepas distintas, sendo este um processo de ocorrência multifatorial, não podendo serem generalizados os procedimentos de sanitização.

micro-organismos. A ocorrência de microorganismos na geladeira e no freezer se deve provavelmente a baixa frequência de higienização realizada nestes locais, os quais devem ser objetos de uma sanitização específica. Neste trabalho foi possível isolar um total 46 tipos de bactérias sendo destes 24 Gram-positivas (15 cocos e 9 bacilos) e 16 Gram-negativas (bacilos) e 6 indeterminadas, em pontos usuais de acondicionamento e 
comercialização. Embora ocorra um predomínio de colônias do tipo grampositivas, as bactérias gram-negativas apresentaram motilidade e assim consideradas patogenicamente mais agressivas, sendo identificadas como constituídas por dois gêneros dominantes:
Escherichia e Enterobacter. Informações adicionais sobre compostos indicativos para uma melhor sanitização foram brevemente comentados com o objetivo de sugerir agentes que tenha efetiva ação sobre os organismos identificados.

\section{AGRADECIMENTOS}

Os autores são gratos ao apoio financeiro do CNPq, CAPES, MCTI/SisNano e da Rede AgroNano (Embrapa).

\section{REFERÊNCIAS}

ABURJAILE, F. F.; SANTANA, M. P.; VIANA, M. V. C.; SILVA, W. M.; FOLADOR E. L.; SILVA, A.; AZEVEDO, V. Genomics. In: A Textbook of Biotechnology (Zahoorullah, S. ed.). SM Online Publishers LLC, Dover, DE, USA, 19p. 2015.

ANDRADE, N. J. Higiene na indústria de alimentos: avaliação e controle da adesão e formação de biofilmes bacterianos. São Paulo: Varela, $2^{\text {a }}$. Ed. 412 p., 2014.

BEACH, M. Water, pollution, and public health in China. The Lancet, v.358, n.9283, p.735, 2001.

BLAST: Assembled RefSeq Genomes, 2015. Disponível em http://www.ncbi.nlm. nih.gov/blast.>. Acesso em: 12 out. 2016.

DNA CONSULT: Genética e Biotecnologia. Disponível em <http://www.dnaconsult.com.br/>. Acesso em: 18 out. 2016.

EMBRAPA: Genetic Resources and Biotechnology. Electropherogram quality analysis. Disponível em <http://asparagin. cenargen.embrapa.br/phph/>. Acesso em: 11 dez. 2016.

FABIANO, M. F. Efeito da própolis sobre o crescimento de bacilos gram-negativos móveis coletados em hortifrutigranjeiro. 75p. Dissertação (Mestrado em Biotecnologia) Universidade Federal de São Carlos, UFSCar, 2011.

HALEBIAN, S.; HARRIS, B.; FINEGOLD, S. M; ROLFE R. D. Rapid method that aids in distinguishing grampositive from gram-negative anaerobic bacteria. Journal of Clinical Microbiology, v. 3, n.3, p.444-448, 1981.

HANJRA, M. A.; BLACKWELL, J.; CARR, G.; ZHANG, F.; JACKSON, T. M. Wastewater irrigation and environmental health: Implications for water governance and public policy. International Journal of Hygiene and Environmental Health, v.215, n.3, p.255269.

JAY, J. M. Microbiologia de alimentos. Porto Alegre: Artmed, p.355-383. 2005.

KIEL, S. The vent and seep biota: Aspects from microbes to ecosystems. Topics in Geobiology, vol. 33, N. York: Springer, 2010, 490p.

MARTINEZ, V. A.; SCHWARZ-LINEK, J.; REUFER, M.; WILSON, L. G.; MOROZOV, A. N.; POON, W. C. K. Flagellated bacterial motility in polymer solutions. PNAS, v.111, n.50, p.1777117776, 2014. 
MINISTÉRIO DA SAUDE: Manual Integrado de Vigilância, Prevenção e Controle de Doenças Transmitidas por Alimentos. Secretaria de Vigilância em Saúde, Brasília, DF., 158p., 2010

MORETTI, P. E. Microbiologia: Fundamentos e Aplicações, 2008. Disponível em <http://www.fam.br/ microrganismos>. Acesso em: 19 ago. 2016.

PINHEIRO, A. B.; SANTOS, D. M.; BUKZEM, A. L.; VIEIRA, J. A. Sanitização de frutas e hortaliças na indústria de alimentos. In: VI JORNADA DE PESQUISA E PÓS-GRADUAÇÃO E SEMANA NACIONAL DE CIÊNCIA E TECNOLOGIA. 19 a 21 de outubro, 2011, Anais... Universidade Estadual de Goiás, $6 \mathrm{p}$.

POMMERVILLE, J. C., Alcamo's Laboratory Fundamentals of Microbiology. 10th ed. Jones \& Bartlett Lerning Edition, Sudbury, MA., 356 p., 2013

SATOLLO, N. M .S.; DE BRITTO, D.; ASSIS, O. B. G. Quitosana como fungicida em madeiras Pinus sp. empregadas na confecção de caixas " $\mathrm{K}$ ". Brazilian Journal of Food Technology, v.13, n.2, p.128-132, 2010.

SARANRAJ, P.; STELLA, P.; REETHA, D. Microbial spoilage of vegetables and its control measures: A review. International Journal of Natural Product Science, v.2, n.2, p.1-12, 2012; 